\title{
Floristic-phytosociological approach, potential natural vegetation, and survival of prejudice
}

\author{
Ladislav Mucina (*)
}

\begin{abstract}
Mucina, L. 2010. Floristic-phytosociological approach, potential natural vegetation, and survival of prejudice. Lazaroa 31: 173-182 (2010).

Carrión \& Fernandez (2009; further C\&F) in a recent commentary on a paper published in Journal of Biogeography criticised an obvious mismatch between the predictions about the patterns of potential natural vegetation (PNV) made by phytosociologists, and those underpinned by pollen data. C\&F used this stage to take a broad sway on phytosociology in general (stopping only very short of denying it status of science), blaming power of tradition and influence of personal cult for ignoring scientific evidence. In my response I show that $\mathrm{C} \& \mathrm{~F}$ have misinterpreted the concept of PNV, rendering their comparisons irrelevant. $\mathrm{C} \& \mathrm{~F}$ obviously overslept the progress descriptive vegetation science made in recent decades, relegating their heavy criticism of phytosociology into the realm of prejudice.
\end{abstract}

Keywords: descriptive vegetation science, phytosociology, personality, potential natural vegetation, reconstructed natural vegetation, Spain, vegetation mapping

Resumen: Mucina, L. 2010. Supervivencia de prejuicios en el concepto de vegetación potencial natural, y en las aproximaciones florística-fitosociológica. Lazaroa 31: 173-182 (2010).

Carrión y Fernández (2009; C\&F) en un comentario recientemente publicado en Journal of Biogeography han criticado la falta de relación entre las predicciones que sobre modelos de vegetación natural potencial (PNV) han hecho los fitosociólogos, y aquellas sostenidas por datos polínicos, utilizando este hecho para hacer una crítica amplia y general de la fitosociología, negándola, aunque de forma breve, el estatus de ciencia. Estos autores han argumentado el poder de la tradición y de la influencia del culto personal como principales responsables de una cierta falta de evidencia científica. En mi respuesta muestro que han malinterpretado el concepto de PNV, además han obviado el progreso que se ha realizado en las ciencias de la vegetación en las últimas décadas, cayendo sus críticas en meros prejuicios.

\section{INTRODUCTION}

CARRIÓN \& FERNÁNDEZ (2009; further C\&F) in a recent commentary consider the DE NASCIMIENTO \& al.'s (2009) paper to be "adding to a growing body of work questioning the floristicphytosociological approach of traditional vegetation science". These authors found it upsetting that palynological evidence does not match (presumed) projections made by phytosociologists about the past vegetation patterns in Spain. Consequently they complained about survival of (in- appropriate or inadequate?) phytosociological models of vegetation dynamics, neglecting scientific evidence because of the "issues of tradition and authority". C\&R also called Spain "the last 'academic refuge' of floristic phytosociology". (sic!)

I do share some of their concern about the unduly profound influence of some eminent and mainly self-styled leading European personalities in phytosociology, and in particular those often more interested in building their 'personal cults' than the scientific discipline itself. I am also con-

\footnotetext{
* Department of Environment \& Agriculture. Curtin University. GPO Box U1987. Perth. WA 6845. Australia. E-mail: L.Mucina@curtin.edu.au
} 
cerned about the dogmatic ways phytosociology (I fact vegetation ecology, ecology, if not science in general) had been practised in some countries in the (not so distant?) past. Some of the C\&F's complaints and doom-says about floristic phytosociology are, however, based on poor understanding of crucial concepts of vegetation science, obviously fuelled by groundless expectations about the aims and abilities of the floristic-phytosociological (or rather "floristicsociological" as known to vegetation scientists) approach to vegetation science. C\&F apparently overslept the developments of the past couple of decades in vegetation science altogether.

I strongly feel that that leaving remarks and conclusions made by $\mathrm{C} \& \mathrm{~F}$ on pages of Journal of Biogeography unchallenged would deny my scientia amabilis, and many hard-working vegetation scientists in general, a fair go. It is, also, an invitation to serious and fair engagement - an exchange of views on the ways vegetation science is done today and should be done in future. My intention to submit this short response note to Journal of Biogeography was discouraged by the journal's Editor-in-Chief, leaving me not many options except for offering my thoughts to a journal "closer to home". I believe that the Lazaroa's readership should be equally concerned about the C\&F's remarks and observations as are those reading Journal of Biogeography.

My response will address two issues: (1) the misconception about the aims and abilities of "floristic-phytosociological approach" in dealing with vegetation patterns, and (2) wrong interpretation of the concept of potential natural vegetation (PNV).

\section{WHAT PHYTOSOCIOLOGY DOES AND WHAT IT CANNOT DO?}

Floristic-sociological Approach (BRAUNBlanquet, 1964; WesthofF \& VAN DER MAAREL, 1978) or Braun-Blanquet Approach (VAN Der MAARel, 1975) as is the preferred term to call "phytocoenology" or "phytosociology" is about 100+ years old - well seasoned, established and in many respect "traditional". (I do not know any science which is not building on tradition.) It still does indulge too much (to my tastes) in antiques such as awkward nomenclature of plant communities and lack of methodical rigour in places. It has not been a stranger to offering space for emergence of towering personalities which might have served as great leaders and catalysers of progress in the past, unfortunately later turned too authoritative and stubborn just to become liability for progress and for broad social acceptance of vegetation science. Central European countries had their share of such authorities in the past, while some South European countries (such as Spain and Italy) are trying to put this past behind as well. Challenges facing Spanish scientific society have been are well publicised (e.g. Navarro \& Rivero, 2001; Cirdero Rivera, 2003) and it may well be that the curricula of some (maybe even many) Spanish universities still indulge in "traditional" authoritative (oldfashioned or even antique) ways of teaching and doing vegetation science. Still it is not difficult to see that Spanish vegetation science moved on - it has diversified and the face of Spanish descriptive vegetation science (some may prefer to call it phytosociology) is changing too. I was witness to this new winds first hand for instance at the 2007 Jornadas de Fitosociología in Madrid. By the way, in South Africa traditional phytosociology has been taught at the University of Pretoria (until recently), in Bloemfontein at the University of the Free State as well as on couple of small campuses in the north of the country. No much "damage" done there, I recon. Except perhaps for the fact that by classical phytosociology now taking back seat in South Africa, we might be loosing a lot of biodiversity expertise in the country and definitely get much less reliable vegetation field data. And without those any update of vegetation map of southern Africa (Mucina \& Rutherford, 2006) would become a struggle.

$\mathrm{C} \& \mathrm{~F}$ claim that there is a "growing body of work questioning the floristic-phytosociological approach of traditional vegetation science". I am afraid this statement would have to remain a hand-waving argument, since no source of such criticism was cited by $\mathrm{C} \& \mathrm{~F}$. In fact the Working 
Group "European Vegetation Survey" (EVS; e.g. Mucina \& al., 1993; PignatTi, 1995; Rodwell \& al., 2005) dealing undoubtedly with the most "traditional" topics of vegetation science is the most active scientific forum within the well-established International Association for Vegetation Science. The core business of EVS is the description and interpretation on vegetation patterns in Europe, acting as catalyser of unification of conceptual and terminological tools over now united Europe, and serving as forum for development of a new platform for descriptive vegetation science and theoretical vegetation science. The vegetation survey, description, and mapping have regained firm ground in science and society - many national vegetation surveys have been initiated and finalised (see Mucina, 2000 for a survey), compatible national databases have been built and new borderline projects linking vegetation science with macroecology, nature conservation, climatology, palaeoecology have been initiated. The achievements in the field of vegetation mapping are difficult to overlook as they becoming rapidly citation classics (e.g. MucinA $\&$ RUTHERFORD, 2006). Because of its versatility, solid methodical background and close relationship with applied aspects of nature management and conservation, vegetation survey and mapping set firmly foot in countries using other traditionally tools to describe vegetation such as in Russia and Ukraine (in both countries new phytosociological journals were founded), United Kingdom (now fully integrated within EVS), China, Korea, Australia. Interestingly, phytosociology seem to have regained respect in United Kingdom (RoDwell, 1991-2000), northern Europe (LAWESSON \& al., 1997), and United States of America (JENNINGS \& al., 2009), traditionally opposing classical floristic-sociological approach. That is not a face of science which would be seeking "refuges" (C\&F, p. 2203) or fearing extinction.

Floristic-sociological approach is very powerful in handling static vegetation patterns. It is a great tool (albeit not the only one) in capturing and describing variability of vegetation. However the traditional sampling, data-handling and interpretational tools used by phytosociology are very poorly suited to capture vegetation dynamics and describe and explain vegetation palaeopatterns. (I would argue that equally poorly performs palynology in regions devoid of sediments able to preserve pollen.) In the deep past the ideas of directional and deterministic development and climax (a strive for equilibrium) all concepts usually associated with legendary Frederick Clements, although we might be blaming him for too much- have pervaded thinking in science of vegetation dynamics (syndynamics as called by classical phytosociological texts). Phytosociologists took the liberty, often without having hard data in hands and used to jump often to conclusions using purely speculative means. Indeed older phytosociological literature abounds with magic plexus diagrams showing how one community would be replace the other, usually in order to achieve climax of some sort. Obviously speculations are often very inspiring, but testing well-defined hypotheses and collecting hard data is always better. Sometimes phytosociologists obviously have been engaging in a sort of informal predictive and retrospective modelling, however often without having documented properly the parameters, procedures, conditions and admitting caveats. Here I share the frustration of $C \& F$ with the failure of this approach to match solid palaeo-ecological evidence. Still, there is another source of misunderstanding which might put the $C \& F^{\prime}$ s frustrations into a perspective: the failure of $C \& F$ to recognize what the concepts of PNV (and related) were meant to address.

\section{POTENTIAL NATURAL VEGETATION VERSUS RECONSTRUCTED NATURAL VEGETATION}

I am not questioning $C \& R$ analysis of the discrepancies and fits between the vegetation patterns "predicted" ("reconstructed" rather) by PNV and those reconstructed using pollen data for mid-Holocene. Herewith $\mathrm{C} \& \mathrm{~F}$ provided very exciting food for deep thought. A source of $m y$ frustration is that C\&F got it wrong in the conceptual issues: The concept of PNV was not ex- 
plicitly coined to serve reconstruction of vegetation patterns in "pre-human" times, hence before serious agricultural and silvicultural land-use changed face of the modern vegetation landscapes. Neither was in fact concept of reconstructed natural vegetation (RNV; HEJNÝ, 1963; NEUHÄUSL, 1963; MoRAVEC, 1998; see also Table 1) coined to do so. I argue that neither of these two concepts was meant to reconstruct deep-time vegetation patterns. Mid-Holocene was a long time ago and much happened to the vegetation of the Iberian Peninsula, Balearic Islands, Canary Islands, or Europe for that matter, ever since. The vegetation changes since mid-Holocene were driven both by the changes of climate (as C\&F also reluctantly admit, and perhaps also slightly underestimate) and by intensive human use of the European landscapes (here our opinions cannot concur more).

The concept of PNV is indeed a traditional tool of descriptive vegetation science, and vegetation mapping in particular. In its original shape TÜXEN (1956) suggested that PNV is an "imagined natural state of vegetation ... that could be outlined for the present time or for a certain earlier period, if human influence on vegetation was removed - the remaining conditions of life presently existing or having existed during those periods still being valid - and the natural vegetation was imagined as switched into the new balance within a split second ... to exclude the possible effects of climatic changes and the consequences thereof" (the English translation follows HäRDTLE, 1995).

The original as well as later modifications of the PNV concept do not evoke pre-human (pre agriculture?) times, but speculates about how would vegetation look like if the influence of man was removed. The sister concept of RNV is very similar to PNV (see MORAVEC, 1998 for detailed comparative analysis of both) as it attempt to reconstruct vegetation without man (or perhaps before human influence became landscape-shaping factor), but does so by using causal/correlative link between the current environment, hence basing its raison d'être on the basic paradigm of vegetation science - vegetation is a reflection (or indicator) of environmental conditions. (I am well aware of the fact that this paradigm should undergo serious scrutiny in attempt to incorporate the influence of history and evolutionary assembly rules, or maybe should be trashed in favour of a new paradigm altogether.)

The critical assessment of the original PNV concept by both vegetation theoreticians and its use by practical vegetation mappers (for the evolution of the PNV and related mapping concepts see Table 1) revealed clearly that the weak points. Some of those had been dealt with (e.g. KowARIK, 1987; HÄRDTLE, 1995; LEUSCHNER, 1997), some remain. In any case, the original applications of PNV concept which served vegetation mapping were resting on many (often problematic) assumptions on, directional and non-probabilistic vegetation-dynamics pathways. This assumption-driven approach is luckily loosing its ground. Vegetation mapping methodology moved on, leaning heavily on technology-driven progress in use of satellite imagery, GIS technology, and formalised predictive modelling (see FRANKLIN, 1995 for a review, and BRZEZIECKI \& al., 1993; FisCHER, 1994; TICHÝ, 1999; LIU \& al., 2009 for some important case studies). The concepts of PNV and RNV did play their important historical roles in getting where we are in vegetation mapping today.

In summary, C\&F's criticism of phytosociology (descriptive vegetation science) does not appear to have been well informed. This is hardly acceptable nowadays when information is readily available on push of a button, and when crossdisciplinary cooperation is the norm. Perhaps looking over the fence to check what neighbours are doing would not do any harm - it might prevent embarrassing unduly indiscriminative and ill-informed statements as those offered by $C \& F$ in their Journal of Biogeography paper. Well, they are at least in good company (see Moore, 1990 and response by MorAVEC, 1992). Old habits and prejudice obviously die hard.

\section{ACKNOWLEDEMENGTS}

My thanks go to Andraž Čarni, Milan Chytrý, Christoph Leuschner and Bea Oborny for providing some less accessible literature sources. 
Table 1

Historical highlights of the conceptual, methodological and terminological development, and applications of the Potential Natural Vegetation and related concepts.

\begin{tabular}{|c|c|c|c|}
\hline Year & Source & Concept & Note \\
\hline 1956 & Tüxen (1956) & PNV & $\begin{array}{l}\text { original definition of Potential Natural Vegetation: "imagi- } \\
\text { ned natural state of vegetation ... that could be outlined for the } \\
\text { present time or for a certain earlier period, if human influence } \\
\text { on vegetation was removed - the remaining conditions of life } \\
\text { presently existing or having existed during those periods still } \\
\text { being valid-and the natural vegetation was imagined as swit- } \\
\text { ched into the new balance within a split second ... to exclude } \\
\text { the possible effects of climatic changes and the consequences } \\
\text { thereof" (translation by Härdtle 1995) }\end{array}$ \\
\hline 1963 & Tüxen (1963) & PNV & review on types of vegetation maps \\
\hline 1963 & Neuhäusl (1963) & RNV & $\begin{array}{l}\text { original definition of Reconstructed Natural Vegetation: "re- } \\
\text { construction of natural vegetation corresponding to the present } \\
\text { climate"; see also Hejný (1963) }\end{array}$ \\
\hline 1964 & Küchler (1964) & PNV & application of PNV: vegetation map of conterminous USA \\
\hline 1966 & Trautmann (1966) & PNV & $\begin{array}{l}\text { first application of PNV: vegetation map of West Germany } \\
\text { (mapping sheet Minden); for the list of other maps of this se- } \\
\text { ries see Schröder (1984) and Bohn et al. (2003) }\end{array}$ \\
\hline 1967 & Küchler (1967) & PNV & $\begin{array}{l}\text { brief textbook account of the concept of PNV and mapping ap- } \\
\text { plications }\end{array}$ \\
\hline 1968 & Mikyška et al. (1968) & RNV & $\begin{array}{l}\text { modification of the concept of RNV: "reconstruction considers the } \\
\text { past state of the natural vegetation before its deterioration or even } \\
\text { destruction by man"; first application of RNV: vegetation map of } \\
\text { Czechoslovakia (the Czech Lands; today: Czech Republic) }\end{array}$ \\
\hline 1968 & Zólyomi (1968) & RNV & application of RNV: vegetation map of Hungary \\
\hline 1971 & Wagner $(1$ & PNV & $\begin{array}{l}\text { application of PNV: vegetation map of Austria; see also Wag- } \\
\text { ner (1989) }\end{array}$ \\
\hline 1975 & Neuhäusl (1975) & PNV & $\begin{array}{l}\text { theoretical discussion; use of PNV in mapping of vegetation } \\
\text { of "cultural landscapes" (= landscapes transformed under in- } \\
\text { fluence of man) }\end{array}$ \\
\hline 1975-1989 & $\begin{array}{l}\text { Miyawaki et al. } \\
(1975-1989)\end{array}$ & PNV & $\begin{array}{l}\text { monumental series of maps of PNV of Japan; see also Miyawaki } \\
\text { \& Fujiwara (1988) }\end{array}$ \\
\hline 1977 & Kowarik (1977) & PNV & $\begin{array}{l}\text { crucial critical analysis of the PNV concept and suggestions } \\
\text { for more operational definition of PNV }\end{array}$ \\
\hline 1978 & $\begin{array}{l}\text { Stumpel \& } \\
\text { Kalkhoven (1978) }\end{array}$ & PNV & $\begin{array}{l}\text { addition of constrictions on the original PNV concept, concerning } \\
\text { the period of development and the human influence }\end{array}$ \\
\hline 1984 & Neuhäusl (1984) & ecPNV & $\begin{array}{l}\text { introduction of Environment-Consistent PNV (in German: } \\
\text { "umweltgemässe natürliche Vegetation"), defined as "vege- } \\
\text { tation which develops if all direct and indirect (by house ani- } \\
\text { mals etc.) interventions would cease" }\end{array}$ \\
\hline 1984 & Matuszkiewicz (1984) & PNV & $\begin{array}{l}\text { application of PNV: vegetation map of Poland; see also Fa- } \\
\text { liński (1971) }\end{array}$ \\
\hline 1985 & Quézel \& Barbero (1985) & PNV & application of PNV: vegetation map of East Mediterranean \\
\hline 1986 & Michalko et al. (1986) & RNV & $\begin{array}{l}\text { application of RNV: vegetation map of Czechoslovakia (part: } \\
\text { Slovakia) }\end{array}$ \\
\hline 1986 & (1986) & PVN & application of PNV: vegetation map of Yugoslavia \\
\hline 1987 & Schiechtl (1987) & PNV & application of PNV: vegetation map of Tyrol (Austria) \\
\hline 1988 & $\begin{array}{l}\text { Kalkhoven \& } \\
\text { van der Werf (1988) }\end{array}$ & PNV & $\begin{array}{l}\text { review of PNV mapping in major mapping textbook (Küchler \& } \\
\text { Zonneveld 1988) }\end{array}$ \\
\hline 1989 & Fukarek et al. (1989) & PNV & $\begin{array}{l}\text { application of PNV: vegetation map of Yugoslavia; see also } \\
\text { Fukarek (1980) }\end{array}$ \\
\hline
\end{tabular}




\begin{tabular}{|c|c|c|c|}
\hline 1990 & Fischer (1990) & PNV & $\begin{array}{l}\text { methodical account of modelling methodology of formalised } \\
\text { mapping of PNV }\end{array}$ \\
\hline 1991 & Moravec et al. (1991) & RNV & $\begin{array}{l}\text { application of RNV: vegetation map of Prague (the the capital } \\
\text { city of Czech Republic) }\end{array}$ \\
\hline 1992 & $\begin{array}{l}\text { Martínez-Tabernet } \\
\text { et al. (1992) }\end{array}$ & PNV & $\begin{array}{l}\text { interesting and rare application fo the PNV methodology to map } \\
\text { submerged (azonal) vegetation }\end{array}$ \\
\hline 1993 & Ivan et al. (1993) & PNV & application of PNV: vegetation map of Romania \\
\hline 1993 & Brzeziecki et al. (1993) & PNV & $\begin{array}{l}\text { application of formalised modelling approach to simulate map } \\
\text { of potential nature forest vegetation of Switzerland }\end{array}$ \\
\hline 1993 & Pedrotti (1993) & PNV & application of PNV: vegetation map of Italy \\
\hline 1994 & $\begin{array}{l}\text { Dierschke } \\
(1994, \text { pp. 446, 558) }\end{array}$ & PNV & brief textbook account of PNV mapping procedures \\
\hline 1995 & Box (1995b) & PDV & $\begin{array}{l}\text { introduction of concept of Potential Dominant Vegetation: } \\
\text { "the potential dominant vegetation is essentially a somewhat } \\
\text { generalized version of the potential natural vegetation of an } \\
\text { area and is predicted from relatively conservative climatic en- } \\
\text { velopes which represent the 'ecological limits' of the vegetation } \\
\text { types rather than the physiological limits of the dominant } \\
\text { taxa"; see also Box (1995a) and Box \& Fujiwara (2005) }\end{array}$ \\
\hline 1995 & Cha (1995) & PNV & $\begin{array}{l}\text { link between PNV and predictive modelling using climatic } \\
\text { data (Kira scheme) }\end{array}$ \\
\hline 1995 & Franklin (1995) & PNV & review of methods and progress in predictive vegetation mapping \\
\hline 1995 & Härdlte (1995) & PNV & $\begin{array}{l}\text { crucial critical analysis of the PNV concept (especially from } \\
\text { the point of view of past application of PNV) and suggested } \\
\text { modifications }\end{array}$ \\
\hline 1996 & Lindacher (1996) & PNV & critical account of the mapping methodology of PNV \\
\hline 1997 & Leuschner (1997) & PNV & review of the concept of PNV, weaknesses and perspectives \\
\hline 1997 & Neuhäuslová et al. (1997) & PNV & $\begin{array}{l}\text { application of PNV: vegetation map of Czech Republic (Czech } \\
\text { version) }\end{array}$ \\
\hline 1998 & Zerbe (1998) & PNV & $\begin{array}{l}\text { theoretical discussion about validity and applicability of the } \\
\text { PNV concept in landscape planning and nature conservation }\end{array}$ \\
\hline 1998 & Miyawaki (1998) & PNV & $\begin{array}{l}\text { discussion of use of the concept of PNV in restoration ecology; } \\
\text { see also Miyawaki (2004) }\end{array}$ \\
\hline 1998 & Moravec (1998) & $\mathrm{PNV}, \mathrm{RNV}$ & theoretical discussion of the concepts \\
\hline 1998 & Chytrý (1998) & PRV & $\begin{array}{l}\text { introduction of the concept of Potential Replacement Vege- } \\
\text { tation defined as: } \\
\text { "an abstract and hypothetical vegetation which is in balance } \\
\text { with climatic and soil factors currently affecting a given habitat, } \\
\text { with environmental factors influencing the habitat from outside } \\
\text { such as air pollution, and with an abstract anthropogenic in- } \\
\text { fluence (management) of given type, frequency and intensity" }\end{array}$ \\
\hline 1999 & Tichý (1999) & PNV & use of predictive modelling approach to construct the map of PNV \\
\hline 1999 & $\begin{array}{l}\text { Zimmermann \& } \\
\text { Kienast (1999) }\end{array}$ & PNV & use of predictive modelling approach to construct the map of PNV \\
\hline 2000 & Ricotta et al. (2000) & PNV & using PNV to assess the diversity of landscapes \\
\hline 2001 & Neuhäuslová et al. (2001) & PNV & $\begin{array}{l}\text { application of PNV: vegetation map of Czech Republic (Eng- } \\
\text { lish version) }\end{array}$ \\
\hline 2001 & Vuerich et al. (2001) & PNV & use of PNV methodology to map also azonal vegetation \\
\hline 2002 & Ricotta et al. (2002) & PNV & $\begin{array}{l}\text { theoretical analysis of relationships between PNV and neutral } \\
\text { landscape models }\end{array}$ \\
\hline 2002 & Vázques et al. (2002) & PNV & application of PNV concept to compare fire regime patterns \\
\hline 2002 & Schmidt et al. (2002) & PNV & vegetation map of PNV of Saxony (Germany) \\
\hline 2003 & Bohn et al. (2003) & PNV & $\begin{array}{l}\text { application of PNV: vegetation map of Europe; see also Neu- } \\
\text { häusl (1991) }\end{array}$ \\
\hline
\end{tabular}




\begin{tabular}{|c|c|c|c|}
\hline 2004 & Pedrotti (2004) & PNV & detailed discussion of PNV in a mapping textbook \\
\hline 2006 & Cross (2006) & PNV & $\begin{array}{l}\text { application of PNV: vegetation map of Ireland; see also Cross } \\
\text { (1998) }\end{array}$ \\
\hline 2007 & Franke \& Köstner (2007) & PNV & study or influence of climate change of PNV of Central Germany \\
\hline 2009 & Liu et al. (2009) & PNV & $\begin{array}{l}\text { application of PNV using modern modelling tools to map ve- } \\
\text { getation of NE China; see also Liu et al. (2004) }\end{array}$ \\
\hline
\end{tabular}

\section{BIBLIOGRAPHY}

Blasi, C., Carranza, M.L., Frondoni, R. \& Rosati, L. - 2000Ecosystem classification and mapping: a proposal for Italian landscapes - Appl. Veg. Sci. 3: 233-242.

Bohn, U., Gollub, G., Hettwer, C., Neuhäuslová, Z., Schlüter, H. \& Weber, H. -2003 - Karte der natürlichen Vegetation Europas. Map of natural vegetation of Europe. Maßstab/Scale 1:2500000 - Federal Agency for Nature Conservation, Bonn.

Box, E.O. - 1995a - Global potential natural vegetation: Dynamic benchmark in the era of disruption - In: Murai, S (Ed.). Towards global planning of sustainable use of the Earth. Pp. 77-95. Elsevier, Amsterdam.

Box, E.O. - 1995b - Factors determining distribution of tree species and plant functional types - Vegetatio 121: 101-116.

Box, E.O. \& Fujiwara, K. - 2005- Vegetation types and their broad-scale distribution - In: van der Maarel, E. (Ed.). Vegetation ecology. Pp. 106-128. Blackwell, Oxford.

Braun-Blanquet, J. -1964- Pflanzensoziologie. Grundzüge der Vegetationskunde 3. Aufl. - Springer, Wien.

Brzeziecki, B., Kienast, F. \& Wildi, O. -1993- A simulated map of the potential natural forest vegetation of Switzerland - J. Veg. Sci. 4: 499-508.

Carrión, J.S. \& Fernández, S. - 2009- The survival of the 'natural potential vegetation' concept (or power of tradition) - J. Biogeogr. 36: 2202-2203.

Cha, G.-S. - 1995 - Potential natural vegetation distribution of the world based on the modified Kira scheme - J. Japan. For. Soc. 77: 455-462.

Chytrý, M. - 1998- Potential replacement vegetation: an approach to vegetation mapping of cultural landscapes - Appl. Veg. Sci. 1: 177-188.

Cordero Rivera, A. -2003- Trends in the evolution of ecology: "Spain is different" - Web Ecol. 4: 14-21.

Cross, J.R. - 1998 - An outline and map of the potential natural vegetation of Ireland - Appl. Veg. Sci. 1: 241-252.

Cross, J.R. - 2006- The potential natural vegetation of Ireland - Proc. R. Irish Acad. 106/2: 65-116.

de Nascimento, L., Willis, K.J., Fernández-Palacios, J.M., Criado, C. \& Whittaker, R.J. - 2009- The long-term ecology of the lost forests of La Laguna, Tenerife (Canary Islands) - J. Biogeogr. 36: 499-514.

Dierschke, H. - 1994 - Pflanzensoziologie - E. Ulmer, Stuttgart.
Faliński, J.B. - 1971 - Methodical basis for map of potential natural vegetation of Poland - Acta Soc. Bot. Pol. 40: 209-222.

Fischer, H.S. - 1990 - Simulating the distribution of plant communities in an alpine landscape - Coenoses 5: 37 43.

Fischer, H.S. -1994- Simulation der räumlichen Verteilung von Pflanzengeselschaften auf der Basis von Standortskarten Dargestellt am Beispiel des MaB-Testgebiets Davos - Veröffentlichungen des Geobotanischen Institutes ETH Stiftung Rübel Zürich 122: 1-143.

Franke, J. \& Köstner, B. -2007- Effects of recent climate trends on the distribution of potential natural vegetation in Central Germany — Int. J. Biometeorol. 52: 139-147.

Franklin, J. - 1995- Predictive vegetation mapping: geographic modelling of biospatial patterns in relation to environmental gradients - Progr. Phys. Geogr. 19: 474-499.

Fukarek, P. - 1980 - Entwurf einer Vegetationskarte Jugoslawiens im Maßstab 1:1.000.000 - Folia Geobot. Phytotax. 15: 183-189.

Fukarek, P. et al. - 1989- Karta prirodne potencijalne vegetacije SFR Jugoslavije - Skopje.

Härdtle, W. -1995 - On the theoretical concept of the potential natural vegetation and proposals for an up-to-date modification - Folia Geobot. Phytotax. 30: 263-276.

Hejný, S. 1963 Die Wege und Methoden der Vegetationskartierung in Böhmen und Mähren. In: Tüxen, R. (Ed.). Bericht über das Internationale Symposium für Vegetationskartierung 23-26.3.1959 in Stolzenau. Pp. 261-263. J. Cramer, Weinheim.

Ishigami, Y., Shimizu, Y., Omasa, K. - 2002 - Estimation of potential natural vegetation distribution in Japan using a process model - J. Agric. Meteorol. 58: 123133. (in Japanese)

Ivan, D., Donița, N., Coldea, G., Sanda, V., Popescu, A., Chifu, T., Boşcaiu, N., Mititelu, D., Pauca-Comanescu, M. - 1993- Végétation potentielle de la Roumanie Braun-Blanquetia 9: 1-79.

Jennings, M.D., Faber-Langendoen, D., Loucks, O.L., Peet, R.K. \& Roberts, D. - 2009- Standards for associations and alliances of the U.S. National Vegetation Classification - Ecol. Monogr. 79: 173-199.

Jovanović, B., Jovanović, R., Zupančić, M. (Eds.) - 1986Prirodna potencijalna vegetacija Jugoslavije - Scientific Council of Vegetation Map of Yugoslavia, Ljubljana. 
Kalkhoven, J.T.R. \& Van der Werf, S. - 1988 - Mapping the potential natural vegetation - In: Küchler, A.W. \& Zonneveld, I.S. (Eds.). Vegetation mapping. Pp. 375386. Kluwer, Dordrecht.

Kowarik, I. - 1987- Kritische Anmerkungen zum theoretischen Konzept der potentiellen natürlichen Vegetation mit Anregungen zu einer zeitgemässen Modifikation - Tuexenia 7: 53-67.

Küchler,A.W. -1964-Potential natural vegetation of the conterminous United States - Am. Geogr. Soc. Spec. Publ. 36: 1-116.

Küchler, A.W. - 1967 - Vegetation mapping - Ronald Press, New York.

Küchler, A.W. - 1988 - The nature of vegetation - In: Küchler, A.W. \& Zonneveld, I.S. (Eds.). Vegetation mapping. Pp. 13-23. Kluwer, Dordrecht.

Küchler, A.W. \& Zonneveld, I.S. (Eds.) - 1988- Vegetation mapping. Kluwer, Dordrecht.

Lawesson, J.E., Diekmann, M., Eilertsen, O., Fosaa, A.M. \& Heikkilä, H. - 1997- The Nordic Vegetation Survey: Concepts and perspectives - J. Veg. Sci. 8: 455-458.

Leuschner, C. - 1997- Das Konzept der potentiellen natürlichen Vegetation (PNV): Schwachstellen und Entwicklungsperspektiven - Flora 192: 379-391.

Lindacher, R. - 1996- Verifikation der potentiellen natürlichen Vegetation mittels Vegetationssimulation am Beispiel der TK 6434 'Hersbruck' - Hoppea 57: 5-143.

Liu, H., Wang, L., Yang, J., Nakagoshi, N., Liang, C., Wang, W. \& Lv, Y. - 2009- Predictive modeling of the potential natural vegetation pattern in northeast China - Ecol. Res. 24: 1313-1321.

Liu, H.M., Wu, S.H., Zheng, D. \& Yang, Q.Y. -2004The study on the potential natural vegetation and future prospect - Progr. Geogr. 1: 62-70. (in Chinese).

Martínez-Taberner, A., Ruiz-Perez, M., Mestre, I. \& Fortenza, V. - 1992- Predicting of potential submerged vegetation in a silted coastal marsh, Albufera of Majorca, Balearic Islands - J. Environ. Manag. 35: 1-12.

Matuszkiewicz, W. - 1984- Die Karte der potentiellen natürlichen Vegetation von Polen - Braun-Blanquetia 1: 1-99.

Michalko, J., Berta, J., Magic, D . \& Maglocký, Š. — 1979— Potential natural vegetation - In: Mazúr, E. (Ed.). Atlas of the Slovak Socialist Republic. P. 59. Veda, Bratislava. (in Slovak).

Michalko, J., Berta, J., Magic, D. \& Maglocký, Š. - 1986Geobotanical map of C.S.S.R. Slovak Socialist Republic - Veda, Bratislava.

Mikyška, R. et al. -1968- Geobotanical map of Czechoslovakia 1. Czech Lands - Academia, Praha. (in Czech).

Miyawaki, A. \& Fujiwara, K. - 1988- Vegetation mapping in Japan - In: Küchler, A.W. \& Zonneveld, I.S. (Eds.). Vegetation mapping. Pp. 427-441. Kluwer, Dordrecht.

Miyawaki, A. - 1998 - Restoration of urban green environments based on the theories of vegetation ecology - Ecol. Engin. 11: 157-165.
Miyawaki, A. -2004- Restoration of living environment based on vegetation ecology: Theory and practice - Ecol. Res. 19: 83-90.

Miyawaki, A., Aizawa, Y., Fujiwara, K., Hukushima, T., Kim, J., Kim, S., Matsui, H., Matsuda, Y., Minamikawa, M., Murakami, Y., Nakamura, Y., Ohno, K., Okuda, S., Sasaki, Y., Shimizu, T., Suzuki, K., Suzuki, S., Tohyama, M. \& Wada, K. -1985- Vegetation of Japan. Vol. 6. Chubu - Shibundo, Tokyo. (in Japanese with English and German summaries).

Miyawaki, A., Fujiwara, K., Fujiwara, R., Iizumi, S., Ishizuka, K., Kashimura, T., Kikuchi, T., Makita, H., Murakami, Y., Naito, T., Nakamura, Y., Ohno, K., Okuda, S., Sasaki, Y., Sugawara, K., Suzuki, K., Suzuki, S. \& Tohyama, M. -1987 - Vegetation of Japan. Vol. 8. Tohoku - Shibundo, Tokyo. (in Japanese with English and German summaries).

Miyawaki, A., Fujiwara, K., Goto, S., Murakami, Y., Nakagoshi, N., Nakanishi, S., Nakamura, Y., Ohno, K., Okuda, S., Suganuma, T., Suzuki, K. \& Suzuki, S. -1984- Vegetation of Japan. Vol. 5. Kinki - Shibundo, Tokyo. (in Japanese with English and German summaries).

Miyawaki, A., Fujiwara, K., Hada, Y., Itoh, S., Miyata, I., Miyoshi, N., Murakami, Y., Nakagoshi, N., Nakanishi, H., Nakamura, Y., Ohno, K., Okuda, S., Sasaki, Y., Shimizu, H., Suzuki, S. \& Toyohara, G. - 1983- Vegetation of Japan. Vol. 4. Chugoku - Shibundo, Tokyo. (in Japanese with English and German summaries).

Miyawaki, A., Fujiwara, K., Ito, K., Kim, J., Murakami, Y., Nakamura, Y., Ohno, K., Okuda, S., Sasaki, Y., Sato, K., Shinjo, H., Suzuki, K., Suzuki, S., Tachibana, H., Tohyama, M., Tsujii, T. \& Tsukada, M. - 1988 - Vegetation of Japan. Vol. 9. Hokkaido - Shibundo, Tokyo. (in Japanese with English and German summaries).

Miyawaki, A., Fujiwara, K., Itow, S., Kawano, K., Murakami, Y., Nakamura, Y., Ohno, K., Okuda, S., Sasaki, Y. \& Suzuki, K. - 1981- Vegetation of Japan. Vol. 2. Kyushu - Shibundo, Tokyo. (in Japanese with English and German summaries).

Miyawaki,A., Fujiwara, K., Kim, J., Murakami, Y., Nakamura, Y., Nomoto, N., Ohno, K., Okuda, S., Sasaki, Y., Suzuki, K., Suzuki, S., Takeuchi, K. \& Tohyama, M. - 1986- Vegetation of Japan. Vol. 7. Kanto - Shibundo, Tokyo. (in Japanese with English and German summaries).

Miyawaki, A., Fujiwara, K., Minowa, R., Mochizuki, R., Murakami, Y., Okuda, S., Sasaki, Y., Suzuki, K. \& Tsurumaki, K. - 1980 - Vegetation of Japan. Vol. 1. Yakushima - Shibundo, Tokyo. (in Japanese with English and German summaries).

Miyawaki, A., Fujiwara, K., Miyagi, K., Murakami, Y., Nakamura, Y., Ohno, K., Ohno, T., Okuda, S., Okutomi, K., Ono, M., Shimizu, Y., Suzuki, K., Suzuki, S. \& Tohyama, M. - 1989 - Vegetation of Japan. Vol. 10. Okinawa and Ogasawara - Shibundo Tokyo. (in Japanese with English and German summaries).

Miyawaki, A., Fujiwara, K., Morimoto, K., Murakami, Y., Nakamura, Y., Okuda, S., Sasaki, Y., Suzuki, K. \& Suzuki, S. 
-1982 - Vegetation of Japan. Vol. 3. Shikoku - Shibundo, Tokyo. (in Japanese with English and German summaries).

Moore, P.D. -1990- Vegetation's place in history - Nature 347: 710 .

Moravec, J. - 1992 - Is the Zürich-Montpellier approach still unknown in vegetation science of the English-speaking countries? - J. Veg. Sci. 3: 277-278.

Moravec, J. - 1998 - Reconstructed natural versus potential natural vegetation in vegetation mapping: a discussion of concepts - Appl. Veg. Sci. 1: 173-176.

Moravec, J., Neuhäus1, R. et al. - 1991 - Natural vegetation of the territory of the capital city Prague and its reconstruction map - Academia, Praha.

Mucina, L. - 2000 - Ecosystems of Europe. - In: Levin, S.A. (Ed.). Encyclopaedia of Biodiversity. Volume 2. Pp. 635-647. Academic Press, San Diego.

Mucina, L., Rodwell, J.S., Schaminée, J.H.J. \& Dierschke, H. - 1993 - European Vegetation Survey: Current state of some national programmes - J. Veg. Sci. 4: 429-438.

Mucina, L. \& Rutherford, M.C. (Eds.) - 2006 - The vegetation of South Africa, Lesotho and Swaziland - SANBI, Pretoria.

Navarro, A. \& Rivero, A. - 2001 - High rate of inbreeding in Spanish universities - Nature 410: 14.

Neuhäusl, R. -1963 - Vegetationskarte von Böhmen und Mähren - Berich. Geobot. Inst. ETH Zürich, Stift. Rübel 34: 107-121.

Neuhäusl, R. - 1975 - Kartierung der potentiell natürlichen Vegetation in der Kulturlandschaft - Preslia 47: 117-128.

Neuhäusl, R. - 1980- Chemischer Zustand der Atmosphäre in Industriegebieten und die natürliche Vegetation - Acta Bot. Acad. Sci. Hung. 26: 139-142.

Neuhäusl, R. -1984- Umweltgemässe natürliche Vegetation, ihre Kartierung und Nutzung für den Umweltschutz - Preslia 56: 205-212.

Neuhäusl, R. - 1991 - Vegetation map of Europe: First results and current state. J. Veg. Sci. 2: 131-134.

Neuhäuslová, Z. (Ed.) -1997 - Map of potential natural vegetation of the Czech Republic - Academia, Praha.

Neuhäuslová, Z., Moravec, J., Chytrý, M., Ložek, V., Rybníček, K., Rybníčková, E., Husová, M., Grulich, V., Jeník, J., Sádlo, J., Jirásek, J., Kolbek, J. \& Wild, J. -2001 - Potential natural vegetation of the Czech Republic - BraunBlanquetia 30: 1-80.

Pedrotti, F. - 1993 - Carta della vegetazione naturale potenziale d'Italia (Scale 1:1.000.000) - Ministero dell'Ambiente, Roma.

Pedrotti, F. - 2004- Cartografia geobotanica - Pitagora Editrice, Bologna.

Pignatti, S. - 1995 - A new spirit in phytosociology - Ann. Bot. (Roma) 53: 9-21.

Quézel, P. \& Barbéro, M. -1985-Carte de la végétation potentielle de la region méditerranéenne. Feuille No. 1: Méditerranée orientale - C.N.R.S., Paris.

Ricotta, C., Carranza, M.L., Avena, G.C. \& Blasi, C. -2000Quantitative comparison of the diversity of landscapes with actual vs. potential natural vegetation - Appl. Veg. Sci. 3: 157-162.

Ricotta, C., Carranza, M.L., Avena, G.C. \& Blasi, C. - 2002Are potential natural vegetation maps a meaningful alternative to neutral landscape models? - Appl. Veg. Sci. 5: 271-275.

Rivas-Martínez, S. -1987- Mapa de las series de vegetación de España (1:400000) - Publ. Minist. Agric., Pesca y Alim., Inst. Nac. Cons. Nat., Madrid.

Rodwell, J.S. (Ed.) - 1991-2000 - British Plant Communities. Volumes 1-5 - Cambridge Univ. Press, Cambridge.

Rodwell, J.S., Cooper, L. \& Winstanley, D. -1995Using computerized maps of actual and potential vegetation for nature conservation - Coll. Phytosoc. 23: 95-102.

Rodwell, J.S., Pignatti, S., Mucina, L. \& Schaminée, J.H.J. - 1995- European vegetation survey: Update on progress - J. Veg. Sci. 6: 759-762.

Schmidt, P.A., Hempel, W., Denner, M., Döring, N., Gnüchtel, A., Walter, B. \& Wendel, D. -2002 - Potentielle natürliche Vegetation Sachsens mit Karte 1:200000 - Saxony State Office for Environment and Geology, Dresden.

Schröder, L. - 1984- Kartenübersicht zur potentiellen natürlichen Vegetation und realen Waldvegetation in der Bundesrepublik Deutschland - Natur und Landschaft 59: 280-283.

Seibert, P. \& Conrad-Brauner, M. - 1995- Konzept, Kartierung und Anwendung der potentiellen natürlichen Vegetation mit dem Beispiel der PNV-Karte des unteren Inntales - Tuexenia 15: 25-43.

Stumpel, A.H.P. \& Kalkhoven, J.T.R. - 1978 - A vegetation map of the Netherlands, based on the relationship between ecotopes and types of potential natural vegetation - Vegetatio 37: 163-173.

Tichý, L. - 1999 - Predictive modeling of the potential natural vegetation pattern in the Podyjí National Park, Czech Republic - Folia Geobot. 34: 243-252.

Trautmann, W. -1966- Erläueterungen zur Karte der potentiellen natürlichen Vegetation der Bundesrepublik Deutschland 1:200 000, Blatt 85 Minden - Schrift. Veg. 1: 1-138.

Tüxen, R. - 1956- Die heutige potentielle natürliche Vegetation als Gegenstand der Vegetationskartierung - Angew. Pflanz. (Stolzenau) 13: 4-42.

Tüxen, R. - 1963 - Typen von Vegetationskarten und ihre Erarbeitung - In: Tüxen, R. (Ed.). Bericht über das Internationale Symposium für Vegetationskartierung in Stolzenau 1959. Pp. 139-154. J. Cramer, Weinheim.

van der Maarel, E. - 1975 - The Braun-Blanquet approach in perspective - Vegetatio 30: 213-219.

Vázquez, A., Pérez, B., Fernández-González, F. \& Moreno, J.M. - 2002- Recent fire regime characteristics and potential natural vegetation relationships in Spain - J. Veg. Sci. 13: 663-676.

Vuerich, L.G., Poldini, L. \& Feoli, E. -2001 - Model for the potential natural vegetation mapping of Friuli Venezia-Giulia (NE Italy) and its application for a bioge- 
ographic classification of the region - Plant Biosyst. 3: 319-336.

Wagner, H. - 1971 - Natürliche Vegetation, Blatt IV/3, 1:300 000 - In: Österreichische Akademie der Wissenschaften (Ed.). Atlas der Republik Österreich. Freytag-Berndt und Artaria, Wien.

Wagner, H. -1989- Die natürliche Pflanzendecke Österreichs (mit der Vegetationskarte von 1971 im Maßstab 1:1.000.000). 2. Aufl. - Verlag. Öster. Akad. Wiss., Wien.

Westhoff, V. \& van der Maarel, E. - 1978 - The BraunBlanquet approach - In: Whittaker, R.H. (Ed.). Classi- fication of plant communities. Pp. 287-399. Dr. W. Junk, The Hague.

Zerbe, S. - 1998 - Potential natural vegetation: Validity and applicability in landscape planning and nature conservation - Appl. Veg. Sci. 1: 165-172.

Zimmermann, N.E. \& Kienast, F. - 1999- Predictive mapping of alpine in Switzerland: species versus community approach - J. Veg. Sci. 10: 469-482.

Zólyomi, B. - 1968- Reconstructed vegetation, 1:1.5 million - In: Radó, S. (Ed.). National Atlas of Hungary. P. 31, Kartográfiai Válllalat, Budapest. (in Hungarian).

Recibido: 8 abril 2010

Aceptado: 18 mayo 2010 